\title{
Response of Coccinella septempunctata and Menochilus sexmaculatus (Coleoptera: Coccinellidae) to their aphid prey, Lipaphis erysimi (Hemiptera: Aphididae) in rapeseed-mustard
}

\author{
JOGENDER S. RANA* \\ Department of Entomology, CCS Haryana Agricultural University, Hisar - 125004, India; e-mail: jrana@hau.ernet.in
}

\begin{abstract}
Key words. Coccinellidae, Coccinella septempunctata, Menochilus sexmaculatus, Lipaphis erysimi, Brassica juncea, Brassica
\end{abstract} campestris, rapeseed, mustard, aphid

\begin{abstract}
During a three year study in rapeseed-mustard crop, the response of two ladybird species, Coccinella septempunctata and Menochilus sexmaculatus was dependent upon density and time of appearance of their prey. Mustard aphid, Lipaphis erysimi appeared during the second (2000 and 2001) and last (2002) week of January. Aphid appearance was highly dependent on the phenological stage of the host plant. It appeared earlier in rapeseed, Brassica campestris var. BSH-1 than mustard, Brassica juncea var. RH-30. The ladybird beetle's eggs were observed in the last week of January, 4-5 weeks before the maximum aphid population. A correlation between aphid number and the abundance of ladybirds' life stages (egg, larva and beetle) on these host plants revealed that the egg and larval density was positively correlated to aphid numbers. Adult beetles, however, did not show significant positive correlation with aphid numbers during all the three years of study. Coccinella septempunctata was more abundant than Menochilus sexmaculatus in these crops. Menochilus sexmaculatus population disappeared earlier than Coccinella septempunctata which was abundant until end of the crop season.
\end{abstract}

\section{INTRODUCTION}

Oilseed Brassicas contribute substantially to the oil economy of the world including India in the form of oil yield and their by-products for industrial use (Bharti et al., 2002). Its production is being substantially destabilised by about three-dozen insect pests. Mustard aphid, Lipaphis erysimi (Kalt.) inflicts major losses to the rapeseed and mustard crops in India. It sucks on the phloem of different plant parts including inflorescence and seed pods resulting in substantial yield losses (Kennedy \& Abou-Ghadir, 1979). Average yield loss of 35.4 to 73.3 percent has been reported from various agro-climatic zones of India with an overall national average figure of $56.2 \%$ in severe cases (Bakhetia, 1983). Since, use of insecticides for the control of this pest leads to serious environmental hazards in the form of pollution, biological control is of vital importance in oilseed Brassicas. Among predators, Coccinella septempunctata L. is an important bio-control agent of $L$. erysimi in these crops (Sinha et al., 1982). Prey density is an important aspect of a predator's response (Solomon, 1949; Way \& Banks, 1958; Hodek, 1966, 1973) and the ladybird response has been shown to depend on initial aphid densities (Mills, 1979; Shipp \& Whitfield, 1991; Wiedenmann \& Smith, 1993; Fan \& Petitt, 1994) and distribution of the prey (Dixon \& Agarwala, 1999). The aim of this study was to record the density dependent response of $C$. septempunctata and M. sexmaculatus towards their aphid prey in rapeseed-mustard crops in a tropical region of India.

\section{MATERIAL AND METHODS}

The area of study was located in Northern India having subtropical climate $\left(29.5^{\circ} \mathrm{N}\right.$ and $\left.75.45^{\circ} \mathrm{E}\right)$, which is a major Brassica crops growing area of the country. The crop was sown in the month of October (2000, 2001, and 2002) following all standard practices for growing rapeseed and mustard (Anonymous, 2000). Brassica campestris var. BSH-1 (henceforth rapeseed in the text) and Brassica juncea var. RH-30 (henceforth mustard in the text) were planted in a randomised block design ( 5 replications) with a plot size of $10 \times 10 \mathrm{~m}^{2}$. A total of 10 plants from each plot were randomly selected and tagged on the initiation of aphid infestation (landing of alates). These plants were observed at weekly intervals for aphids and coccinellids until harvest of the crop. The aphid population was counted on individual plants by adopting a standard scale $(1 \mathrm{~mm}$ long infested twig $=10$ aphids). The correction factor was applied if there was more than one layer of aphids on the same twig by multiplying the number by the respective number of layers. The crop area was located in an unsprayed region to encourage unhindered natural enemy build up. The number of eggs, larvae and beetles of both coccinellid species and aphids were counted weekly starting from standard week 1 (first week of January). Different stages of both coccinellid species were identified after description of Agarwala \& Bardhanroy (1997). To determine the numerical response of two coccinellids species, log of their egg, larva and beetle densities and aphids (peak density) were fitted on a regressed scale. Linear equations were drawn by simple regression method. Aphid densities on two crop species were compared statistically with ANOVA using SAS.

\footnotetext{
* Present address: Institute of Plant Pathology and Plant Protection, George August University, Grisebach str. 6, Goettingen 37077, Germany, e-mail: jrana@gwdg.de
} 

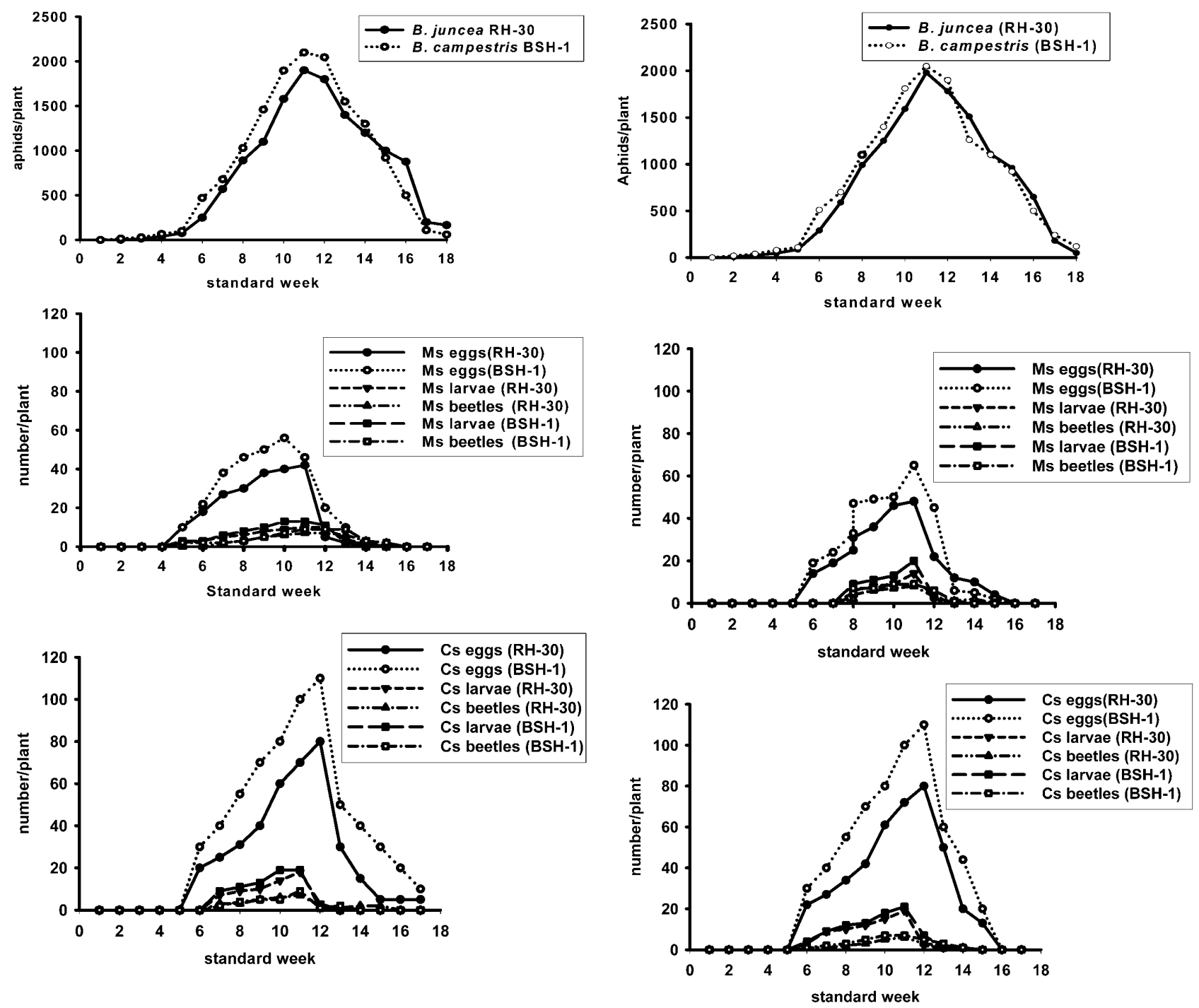

Fig. 1. Abundance of C. septempunctata and M. sexmaculatus in response to population build up of L. erysimi in B. junceaB. campestris crop during the year 2000 .

\section{RESULTS}

\section{Aphid vs. host species}

Aphid infestation in rapeseed appeared earlier than mustard during all the three years of observation. The alates settled on rapeseed during standard week 3. It was noticed that the flower initiation of both crops coincided with alates settling. The population started multiplying and reached to a peak (Figs 1-3) during the $10^{\text {th }}(2000$ and 2002) and $11^{\text {th }}$ week (2001) irrespective of aphid infestation initiation. The average aphid population on rapeseed was consistently greater than on mustard during all the three years of observations (Table 1). The differences in aphid densities between rapeseed and mustard over three years (Table 1) were found statistically different $(F=36.810$, d.f. $=1,5 ; p=0.04)$

\section{Egg laying response}

Both coccinellid species (C. septempunctata and $M$. sexmaculatus) started laying eggs during standard week 4-5 (Figs 1-3) irrespective of the host plant. During the

Fig. 2. Abundance of C. septempunctata and M. sexmaculatus in response to population build up of L. erysimi in B. junceaB. campestris crop during the year 2001 .

first year (2000) of observation, M. sexmaculatus laid significantly more number of eggs on rapeseed (23.07) than on mustard (16.46). Similarly, C. septempunctata laid 52.91 (rapeseed) and 32.16 (mustard) eggs per plant during the same period of observation. During the next year (2001) both ladybird species laid more eggs than in the previous year. In $3^{\text {rd }}$ year of study the number of eggs laid by $M$. sexmaculatus was 42.66 (rapeseed) and 29.41 (mustard) eggs in comparison to 63.8 (rapeseed) and 43.00 (mustard) eggs of $C$. septempunctata. The egg laying response of both ladybird species was positively correlated to aphid numbers (Table 2). Both species had the same peak of abundance in rapeseed and mustard irrespective of the year of infestation. The population of $M$. sexmaculatus was significantly lower than C.septempunctata. The regression coefficients between number of eggs and aphid densities were statistically significant in both host plants $\left(\mathrm{R}^{2}=0.87 ; 0.83\right)$ and coccinellid species $\left(\mathrm{R}^{2}=\right.$ $0.90 ; 0.71)$. 


\section{Larval response}

Number of larvae of $C$. septempunctata was significantly lower than eggs in all combinations (ladybird $x$ crop species $\times$ year). The number of larvae during the year 2002 was significantly higher in rapeseed than mustard as compared to previous years (Figs 1-3). The regression relationship (Table 2) between larval population $\left(\mathrm{R}^{2}=0.72\right.$ on rapeseed and 0.88 on mustard) and aphid density was statistically significant.

The number of larvae was also dependent on the phenological stage of the crop species. Mustard aphid and larval density of coccinellids was significantly higher on rapeseed than mustard, during all three years of observations.

The number of $M$. sexmaculatus larvae was uniformly distributed across three years of observations unlike $C$. septempunctata. The larval density was higher on rapeseed (5.41) than mustard (3.50) during 2001. The regression relationship between larval population $\left(\mathrm{R}^{2}=0.68\right.$ and 0.65 ) and aphid densities in both rapeseed and mustard was positively correlated to the aphid density.

\section{Adult response}

The number of beetles per plant in all the three years of observation was much lower than that of larvae, ranging between 2.16 (mustard) to 4.07 (rapeseed) beetles per plant. The regression response of the beetles to aphid densities was also positive (Table 2) but statistically nonsignificantly for both rapeseed $\left(\mathrm{R}^{2}=0.29\right.$ and 0.39$)$ and mustard $\left(\mathrm{R}^{2}=0.12,0.32\right)$.

\section{DISCUSSION}

The results of the present study in northern plains of India have shown that mustard aphid is a predominant pest of rapeseed and mustard crops frequently varying in its numbers. This pest was more abundant on rapeseed than mustard in all the years of observations. The presence of varying aphid densities may be related to the phenological stage of both rapeseed and mustard since the appearance of aphids coincided with flower initiation of both these crops. This response might have also been due to the inherent tolerance in the latter species (Srinivasachar \& Malik, 1972). The results presented in Figs 1-3 revealed that seven spot ladybird beetle, C. septempunctata was predominant predator in rapeseed and mustard crops. The other species, $M$. sexmaculatus was less abundant and disappeared earlier than $C$. septempunctata. Both larvae and adult stages of two ladybird species were recorded feeding on aphid colonies in these crops. Mustard aphid and coccinellids both appeared simultaneously in week eleven. The occurrence of coccinellids might have been due to either increase in prey availability (Agarwala \& Bardhanroy, 1999) or due to abundance of floral resources as reported for Harmonia axyridis (Lundgren et al., 2004). These arguments led us to propose further study on the importance of plant phenology in the abundance of these predators in these crops.

Prey density dependence among predators is critical to biological control programmes. The abundance of eggs and larvae of $C$. septempunctata and M. sexmaculatus is
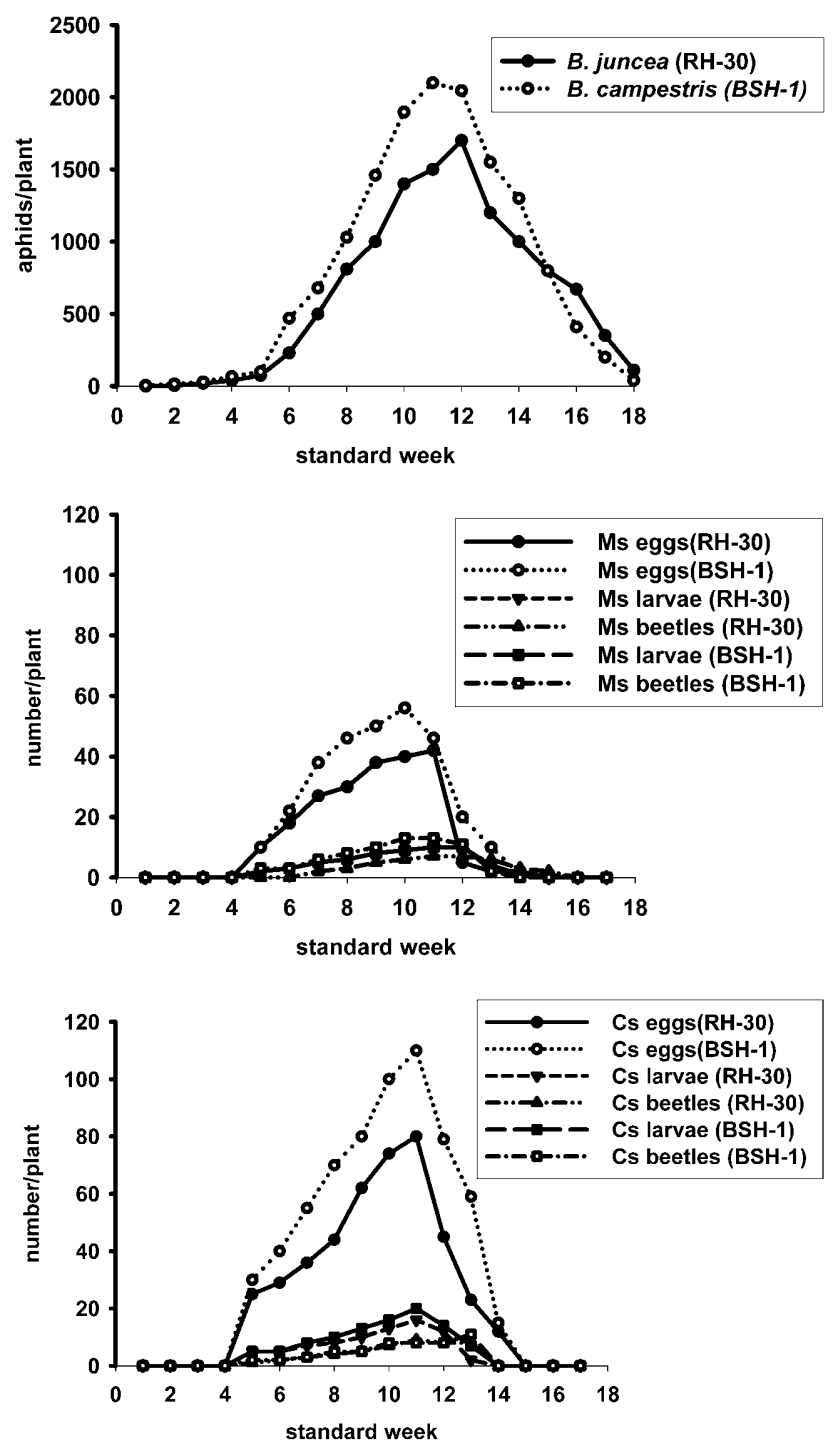

Fig. 3. Abundance of C. septempunctata and M. sexmaculatus in response to population build up of $L$. erysimi in B. juncea B. campestris crop during the year 2002 .

positively correlated with aphid densities in rapeseed and mustard suggesting that these two species are good candidates for biological control of $L$. erysimi. Present results are in agreement with earlier findings (Hodek, 1973; Agarwala \& Bardhanroy, 1997; Dixon 1997; Koch, 2003) on other ladybird species.

The larval response of the ladybird to their aphid prey was also significant (Table 2). Although the larval population was lower than the number of eggs, it successfully

TABLE 1. Aphid infestation in rapeseed-mustard.

\begin{tabular}{ccc}
\hline \multirow{2}{*}{ Year } & \multicolumn{2}{c}{ No. of aphid / plant } \\
\cline { 2 - 3 } & mustard & rapeseed \\
\hline 2000 & $725.72 \pm 12.44^{*}$ & $796.22 \pm 10.90$ \\
2001 & $803.88 \pm 18.11$ & $843.62 \pm 14.89$ \\
2002 & $684.31 \pm 09.33$ & $872.31 \pm 17.33$ \\
\hline
\end{tabular}

$* \pm$ SEM; F (hosts) $=36.810$, d.f. $=1,5 ; \mathrm{p}=0.04 ; \mathrm{F}$ (year of infestation $)=772.52$; d.f. $=4,13 ; \mathrm{p}=0.03$. 
TABLE 2. Regression relationships of C. septempunctata and M. sexmaculatus eggs, larvae and beetle stages and aphid densities in rapeseed-mustard.

\begin{tabular}{|c|c|c|c|c|}
\hline \multirow{3}{*}{ Stage } & \multicolumn{4}{|c|}{ Crop species / regression equation / coefficient $\left(\mathrm{R}^{2}\right)$} \\
\hline & \multicolumn{2}{|c|}{ B. juncea var. RH-30 (mustard) } & \multicolumn{2}{|c|}{ B. campestris var. BSH-1 (rapeseed) } \\
\hline & C. septempunctata & M. sexmaculatus & C. septempunctata & M. sexmaculatus \\
\hline Egg & $\begin{array}{c}\mathrm{Y}=2.42 \mathrm{x}-12.23 \\
\mathrm{R}^{2}=0.87\end{array}$ & $\begin{array}{c}\mathrm{Y}=1.82 \mathrm{x}-08.48 \\
\mathrm{R}^{2}=0.90\end{array}$ & $\begin{array}{c}\mathrm{Y}=0.47 \mathrm{x}+00.22 \\
\mathrm{R}^{2}=0.83\end{array}$ & $\begin{array}{c}\mathrm{Y}=0.64 \mathrm{x}-01.53 \\
\mathrm{R}^{2}=0.71\end{array}$ \\
\hline Larva & $\begin{array}{c}Y=1.39 x-07.06 \\
R^{2}=0.72\end{array}$ & $\begin{array}{c}\mathrm{Y}=1.12 \mathrm{x}-05.88 \\
\mathrm{R}^{2}=0.68\end{array}$ & $\begin{array}{c}\mathrm{Y}=1.16 \mathrm{x}-06.22 \\
\mathrm{R}^{2}=0.88\end{array}$ & $\begin{aligned} \mathrm{Y}= & 1.47 \mathrm{x}-09.12 \\
& \mathrm{R}^{2}=0.65\end{aligned}$ \\
\hline Beetle & $\begin{array}{c}\mathrm{Y}=0.47 \mathrm{x}-01.94 \\
\mathrm{R}^{2}=0.12^{*}\end{array}$ & $\begin{array}{c}\mathrm{Y}=1.15 \mathrm{x}-06.23 \\
\mathrm{R}^{2}=0.32 *\end{array}$ & $\begin{array}{c}\mathrm{Y}=0.21 \mathrm{x}-00.21 \\
\mathrm{R}^{2}=0.29^{*}\end{array}$ & $\begin{array}{c}\mathrm{Y}=1.79 \mathrm{x}-11.58 \\
\mathrm{R}^{2}=0.39^{*}\end{array}$ \\
\hline
\end{tabular}

* Non-significant statistically.

reduced the aphid population in the field. The reduced larval density of coccinellids in comparison to eggs in this crop ecosystem might have been due to large-scale mortality of the egg stage (Majerus, 1994), or due to $30 \%$ cannibalism in earlier larval instars (Mills, 1982; Agarwala \& Dixon, 1992; Osawa, 1992).

One explanation for the lack of a positive response of adult beetles to aphid densities might be their mobility (Hodek, 1973). Adults can move to other crops due to maturity of the crop or due to large scale mortality in this stage. This behavior of coccinellids in these crops might have been due to role of phenological stage of the crop in predator-prey relationship.

The coccinellids studied in the present experiment have a great potential for biological control. This is true particularly for the larvae due to their density dependent behaviour with respect to L. erysimi. Rapeseed and mustard can also serve as a potential reservoir for conservation of these predators for future control of aphid population in these crops.

ACKNOWLEDGEMENTS. The author is indebted to two anonymous reviewers for criticism of the paper and suggestions which led to improvement of the manuscript. Research facilities provided by Head, Department of Entomology and oilseed section CCS HAU Hisar are also acknowledged.

\section{REFERENCES}

Agarwala B.K. \& Bardhanroy P. 1997: Oviposition behaviour and reproduction efficiency in ladybird beetles (Coccinellidae: Coleoptera): a case study of Menochilus sexmaculata (Fabr.). J. Aphidol. 11: 49-59.

Agarwala B.K. \& Bardhanroy P. 1999: Numerical response of ladybird beetles (Coleoptera: Coccinellidae) to aphid prey (Hom.: Aphididae) in a field bean in northeast India. J. Appl. Entomol. 123: 401-405.

Agarwala B.K. \& Dixon A.F.G. 1992: Laboratory studies of cannibalism and interspecific predation in ladybirds. Ecol. Entomol. 17: 303-309.

Anonymous 2000: Package of Practices of Rabi Crops for Northwestern Plain Zone of Haryana. Directorate of Extension Education, CCSHAU, Hisar, 87 pp.

BAKHETIA D.R.C. 1983: Losses in Rapeseed and Mustard Due to Lipaphis erysimi (Kalt.) in India. A literature study. $6^{\text {th }}$ International Rapeseed Conference, Paris, May 16-22, 1983, 87 pp.

Bharti N., Tickoo S., Kaushik A. \& Singh H.B. 2002: An innate defence system in plants. Brassica 4: 34-51.

Dixon A.F.G. 1997: Patch quality and fitness in predatory ladybirds. Ecol. Stud 130: 205-223.
Dixon A.F.G. \& Agarwala B.K. 1999: Ladybird induced life history changes in aphids. Proc. R. Soc. Lond. (B) 266: 1-5.

Fan Y. \& Petitt F.L. 1994: Parameter estimation of the functional response. Environ. Entomol. 23: 785-794.

Hodek I. (ed.) 1966: Ecology of Aphidophagous Insects. Proc. Symp. Liblice near Prague, 1965. Academia, Praha \& Dr. W. Junk, Haag, 360 pp.

Hodek I. 1973: Biology of Coccinellidae. Academia, Praha \& Dr. W. Junk, Haag, 260 pp.

Kennedy G.C. \& ABou-Ghadir M.F. 1979: Bionomics of the turnip aphid on two turnip cultivars. J. Econ. Entomol. 72: 754-757.

Kосн B.L. 2003: The multicolored Asian lady beetle, Harmonia axyridis. A review of its biology, uses in biological control, and non-target impacts. J. Insect Sci. 3: 3-32.

Lundgren J.G., RazzaK A.A. \& Wiedennmann R.S. 2004: Population and food consumption by predators Coleomegilla maculata and Harmonia axyridis (Coleoptera: Coccinellidae) during anthesis in an Illinois cornfield. Environ. Entomol. 33: 958-963.

MaJerus M.J.E. 1994: Ladybirds. Harper Collins, London, 167 pp.

Mills N.J. 1979: Adalia bipunctata (L.) a Generalist Predator of Aphids. Ph.D. thesis, University of East Anglia, $121 \mathrm{pp}$.

MiLls N.J. 1982: Voracity, cannibalism and coccinellid predation. Ann. Appl. Biol. 101: 144-148.

Osawa N. 1992: A life table of the ladybird beetle Harmonia axyridis Pallas (Coleoptera: Coccinellidae) in relation to the aphid abundance. Jap. J. Entomol. 60: 575-579.

Shipp J.L. \& Whitfield G.H. 1991: Functional response of the predatory mite, Amblyseius cucumeris (Acari: Phytoseiidae) on western flower thrips, Franklienella occidentalis (Thysanoptera: Thripidae). Environ. Entomol. 20: 694-699.

Sinha T.B., Pandey R.K., Singh R., Tripathi C.P.M. \& Kumar A. 1982: Functional response of Coccinella septempunctata Linn., a coccinellid predator of mustard aphid, Lipaphis erysimi (Kalt.). Entomon 7: 7-10.

Solomon M.E. 1949: The natural control of animal populations. J. Anim. Ecol. 18: 1-35.

SRINIVASAChaR D. \& MaLIK R.S. 1972: An induced aphid resistant in non-waxy mutant in turnip, Brassica rapa. Current Sci. 41: 820-821.

WAY M.J. \& BANKS C.J. 1958: The control of Aphis fabae Scop. with special reference to biological control of insects which attack annual crops. Proc. $10^{\text {th }}$ International Congr. Entomol., Montreal. Vol. 4. pp. 907-909.

Wiedenmann R.N. \& Smith J.W.JR. 1993: Functional response of the parasitic Cotesia flavipes (Hymenoptera: Braconidae) at low densities of the host Diatraea saccharalis (Lepidoptera: Pyralidae). Environ. Entomol. 22: 849-858.

Received September 22, 2004; revised and accepted October 12, 2005 